IOSR Journal of Pharmacy

e-ISSN: 2250-3013, p-ISSN: 2319-4219, www.iosrphr.org

Vol. 2, Issue 6, Nov-Dec. 2012, PP. 01-04

\title{
Role of Topical Ascorbic Acid in Management of Refractory Corneal Ulcer
}

\author{
Parul Singh ${ }^{1}$, Pushpraj Singh ${ }^{2}$ \\ ${ }^{1}$ Veer Chandra Singh Garhwali Government Medical Science and Research Institute, Srinagar Garhwal, \\ Uttarakhand, India. \\ ${ }^{2}$ Indira Gandhi Eye Hospital and Research Centre, Lucknow, U.P. , India.
}

\begin{abstract}
Ascorbic acid, a water soluble vitamin, helps in collagen assembly, synthesis of neurotransmitters, has immune functions and also acts as a major antioxidant in the body. Refractory corneal ulcer is a challenging situation faced by every ophthalmologist in developing countries. Available treatment options for refractory corneal ulcer are bandage contact lens, grid keratotomy, therapeutic penetrating keratoplasty, amniotic membrane transplantation, nerve growth factors, aprotinin [proteases inhibitor]. These treatment options are costly and require expertise in preparation and use. Topical ascorbic acid has been known to have good results in caustic injury of cornea and in free radical damage after eximer laser surgery. This makes it a potential cost-effective candidate to be studied as an alternative in addition to conservative treatment for treating refractory corneal ulcer. This study aims to study the role of topical ascorbic acid in treatment of refractory corneal ulcers.
\end{abstract}

Keywords: Ascorbic acid, Refractory Corneal Ulcer, Eye

\section{INTRODUCTION}

Ascorbic acid is a water soluble vitamin that helps in collagen assembly, synthesis of neurotransmitters, has immune functions and also acts as a major antioxidant in the body. The high concentration of ascorbic acid in aqueous humor is achieved by its selective transport from plasma perfusing the ciliary body [1]. Topical ascorbic acid has been advocated to promote corneal regeneration as it has been found that the aqueous in most cases of chemical injuries, especially alkali are markedly scorbutic (very low to unrecordable levels of vitamin C). Ascorbic acid is essential for fibroblasts to lay down healthy collagen.

Refractory corneal ulcers are superficial ulcers that heal poorly and tend to reoccur. They are also known as indolent ulcers or boxer ulcers. They are believed to be caused by defect in the basement membrane and lack of hemi-desmosomal attachments. Causes of refractory corneal ulcer are inadequate therapy/ noncompliance; wrong diagnosis; local factors such as increased intraocular pressure, retained foreign body, dacryocystitis, misdirected cilia; and systemic factors like malnutrition, chronic debilitating disease, and diabetes. Conservative treatment of refractory corneal ulcers includes use of topical fortified antibiotics at hourly intervals to treat infectious corneal ulcers. Cycloplegic eye drops are used to give rest to the eye. Pain medications are given as and when needed. Loose epithelium can be scraped off and sent for culture sensitivity studies to find out pathogenic organism. Refractory corneal ulcers can take long time to heal, sometimes even months. In case of progression despite conservative treatment, interventions like bandage contact lens, grid keratotomy, therapeutic penetrating keratoplasty, amniotic membrane transplantation, nerve growth factors, aprotinin [proteases inhibitor] may be required to save the eye. These newer treatment modalities are costly and require expertise in preparation and use.

In all corneal ulcers, it is important to rule out pre-disposing factors like diabetes mellitus and immunedeficiency. This study was done to evaluate response of topical ascorbic acid if any, in established refractory corneal ulcers.

\section{MATERIAL AND METHODS}

This study was done over a period of one year in 46 cases of refractory corneal ulcer having a history of more than one month. Patients with perforated corneal ulcer, marginal ulcer associated with autoimmune disease, hypopyon ulcer and neuroparalytic ulcers were excluded from the study.

Topical ascorbic acid $10 \%$ was used in refractory corneal ulcer in addition to conservative treatment (comprising of topical and systemic antibiotics, topical and systemic antifungal, cycloplegic drugs, systemic analgesic and anti-inflammatory drugs, vitamins, dark goggles, and rest). The efficacy of topical ascorbic acid in improvement of various signs and symptoms of non-healing corneal ulcer was studied. Following signs and 
symptoms were studied at presentation and after one month of treatment: pain, conjunctival congestion, eye opening score, tear break-up time (TBUT), visual acuity, corneal transparency and corneal vascularisation.

Complete ophthalmological examination was done and patients were divided into two groups of 23 patients each. Group A was given conservative treatment along with topical ascorbic acid and Group B was given conservative treatment alone.

\section{Preparation of ascorbic acid eye drop-}

$10 \%$ ascorbic acid injection available was loaded in undiluted form preferably in photo-resistant empty green teal eye drop vial. Ascorbic acid is known to be very unstable and it gets converted into inactive form i.e. dehydroascorbic acid so the patients were asked to use it within 4 days and return for a fresh vial.

\section{RESULTS}

- $\quad$ Out of total 46 patients 17 were male $(36.95 \%)$ and 29 were females $(63 \%)$ [Table 1 ] .

- $\quad 39$ patients $(84.78 \%)$ belonged to low socioeconomic group, 6 patients $(13 \%)$ were from middle and only $1(2.17 \%)$ from high socioeconomic group [Table 2].

- Causes of non- healing corneal ulcer depending on cause as found in our patients belonged to one of the following groups non -compliance 24 patients(52\%), wrong diagnosis 13 patients(28.26\%) and drug toxicity/free radical damage in 9 patients (20\%) [Table 3].

- $\quad$ Gp A: All signs and symptoms except vascularization showed significant statistical difference on follow up [Table 4].

- $\quad$ Gp B: Only pain and conjunctival congestion showed statistical difference on follow up ( $<<0.05)$.Eye opening score, TBUT, visual acuity, corneal transparency and vascularization did not show any statistically important difference [Table 5].

Table 1: Sex incidence

\begin{tabular}{|c|c|c|c|}
\hline MALE & 17 & $17 / 46$ & $36.95 \%$ \\
\hline FEMALE & 29 & $29 / 46$ & $63 \%$ \\
\hline
\end{tabular}

Table 2: Socio-economic status

\begin{tabular}{|c|c|c|}
\hline SOCIOECONOMIC STATUS & NO OF PATIENTS & $\%$ \\
\hline LOW & $39 / 46$ & 84.78 \\
\hline MIDDLE & $6 / 46$ & 13 \\
\hline HIGH & $1 / 46$ & 2.17 \\
\hline
\end{tabular}

Table 3: Causes of non-healing ulcers

\begin{tabular}{|c|c|c|}
\hline CAUSES OF NHCU & NO OF PATENTS & $\%$ \\
\hline NON COMPLIANCE & $24 / 46$ & 52 \\
\hline WRONG DIAGNOSIS & $13 / 46$ & 28.26 \\
\hline DRUG TOXITY/ FREE RADICAL DAMAGE & $9 / 46$ & 20 \\
\hline
\end{tabular}


Role of Topical Ascorbic Acid in Management of Refractory Corneal Ulcer

\begin{tabular}{|c|c|c|c|c|}
\hline \multicolumn{2}{|c|}{ SIGN AND SYMPTOMS } & \multirow{2}{*}{$\begin{array}{c}\text { AT PRESENTATION } \\
1\end{array}$} & \multirow{2}{*}{$\frac{\text { AT I MONTH }}{13}$} & \multirow{2}{*}{$\frac{\text { PVALUE }}{<0.01}$} \\
\hline PAIN & Mild & & & \\
\hline & Mod & 10 & 9 & \\
\hline & Severe & 12 & 1 & \\
\hline \multirow[t]{3}{*}{ CONJ CONGESTION } & Mild & 5 & 16 & \multirow[t]{3}{*}{$<0.01$} \\
\hline & Mod & 14 & 6 & \\
\hline & Severe & 4 & 1 & \\
\hline \multirow[t]{3}{*}{ EYE OPENING SCORE } & Mild & 13 & 1 & \multirow[t]{3}{*}{$<0.01$} \\
\hline & Mod & 8 & 9 & \\
\hline & Severe & 2 & 13 & \\
\hline \multirow[t]{3}{*}{ TBUT } & Immediate & 10 & 3 & \multirow[t]{3}{*}{$<0.01$} \\
\hline & $<5 \operatorname{Sec}$ & 10 & 8 & \\
\hline & $>10 \mathrm{Sec}$ & 3 & 12 & \\
\hline \multirow[t]{3}{*}{ VISUAL ACUITY } & $\mathrm{FCCF}$ & 6 & 1 & \multirow[t]{3}{*}{$<0.01$} \\
\hline & $<6 / 60$ & 16 & 15 & \\
\hline & $>6 / 60$ & 1 & 7 & \\
\hline \multirow[t]{3}{*}{ CORNEAL TRANSPARENCY } & ++ & 5 & 1 & \multirow[t]{3}{*}{$<0.01$} \\
\hline & + & 17 & 13 & \\
\hline & + & 1 & 9 & \\
\hline \multirow[t]{3}{*}{ VASCULARIAZATION } & No & 16 & 17 & \multirow[t]{3}{*}{$<0.05$} \\
\hline & Mild & 3 & 5 & \\
\hline & Mod & 4 & 1 & \\
\hline
\end{tabular}

Table 5: Patients not receiving topical ascorbic acid

\begin{tabular}{|c|c|c|c|c|}
\hline \multicolumn{2}{|c|}{ SIGN AND SYMPTOMS } & \multirow{2}{*}{$\begin{array}{c}\text { AT PRESENTATION } \\
2\end{array}$} & \multirow{2}{*}{$\begin{array}{c}\text { AT } 1 \text { MONTH } \\
10\end{array}$} & \multirow{2}{*}{$\begin{array}{c}\text { P VALUE } \\
\qquad 0.05\end{array}$} \\
\hline PAIN & Mild & & & \\
\hline & Mod & 9 & 8 & \\
\hline & Severe & 12 & 5 & \\
\hline \multirow[t]{3}{*}{ CONJ. CONGESTION } & Mild & 7 & 11 & \multirow[t]{3}{*}{$<0.05$} \\
\hline & Mod & 12 & 10 & \\
\hline & Severe & 4 & 2 & \\
\hline \multirow[t]{3}{*}{ EYE OPENING SCORE } & Mild & 12 & 6 & \multirow[t]{3}{*}{ Not Significant } \\
\hline & Mod & 7 & 10 & \\
\hline & Severe & 4 & 7 & \\
\hline \multirow[t]{3}{*}{ TBUT } & Immediate & 8 & 4 & \multirow[t]{3}{*}{ Not Significant } \\
\hline & $<5 \mathrm{Sec}$ & 11 & 10 & \\
\hline & $>10 \mathrm{Sec}$ & 4 & 9 & \\
\hline \multirow[t]{3}{*}{ VISUAL ACUITY } & FCCF & 5 & 2 & \multirow[t]{3}{*}{ Not Significant } \\
\hline & $<6 / 60$ & 15 & 16 & \\
\hline & $>6 / 60$ & 3 & 5 & \\
\hline \multirow{3}{*}{$\begin{array}{c}\text { CORNEAL } \\
\text { TRANSPARENCY }\end{array}$} & $+1+$ & 4 & 3 & \multirow[t]{3}{*}{ Not Significant } \\
\hline & + & 16 & 14 & \\
\hline & + & 3 & 6 & \\
\hline \multirow[t]{3}{*}{ VASCULARIAZATION } & No & 12 & 14 & \multirow[t]{3}{*}{ Not Significant } \\
\hline & Mild & 6 & 6 & \\
\hline & Mod & 5 & 3 & \\
\hline
\end{tabular}




\section{DISCUSSION}

Corneal stroma is composed of about 200 flattened lamellae (plates of collagen fibrils), superimposed one on another. [2] After injury new collagen needs to be formed and we know that ascorbic acid plays a role in collagen formation.

Hydroxylation of selected proline and lysine amino acids in the newly synthesized procollagen protein takes place and specific enzymes called hydroxylases are responsible for these important reactions. The hydroxylase enzymes require ascorbic acid and iron as cofactors.

Previous studies have demonstrated that when topical ascorbic acid treatment is begun immediately after twenty to thirty five seconds of alkali burns to rabbit cornea, the subsequent incidence of ulceration and perforation is significantly reduced [3,4]. Another study showed that when ascorbate injections raise the level of ascorbic acid in the aqueous humor to near normal levels, the incidence of corneal ulcerations and perforations is significantly reduced in alkali burns [5,6]. Study done by Kasetsuwan et al demonstrated topical ascorbic acid application decrease oxygen radical induced tissue damage following excimer keratectomy. Moreover, topical application of ascorbic acid was shown to reduce the acute inflammatory reaction efficiently [7].

Epithelial cells in wounded cornea are guided into the wound because of wound induced electric field of $\mathrm{Na}+$ and $\mathrm{Cl}+$. Modulating the ions with clinically approved pharmacological agents such as aminophylline, ascorbic acid, or furosemide increased or decreased endogenous wound electric currents. These changes in wound currents correlated directly with the rate of wound healing in vivo [8]. The present study, designed to examine the effect of topical ascorbic acid therapy on established corneal ulcer, has shown promising results in patients treated with topical ascorbic acid along with conservative treatment.

\section{CONCLUSION}

Modern methods of management of refractory corneal ulcers such as amniotic membrane transplant, keratoplasty, stem cell transplantation have considerably improved overall prognosis in unfortunate refractory corneal ulcer patients. But these treatment options are costly and require expertise. This study hints that early use of cheap and freely available alternative like topical ascorbic acid in addition to conservative management may reduce morbidity in these patients. However, more studies with larger group of patients are required to provide conclusive results.

\section{REFERENCES}

[1] Davson H: The intraocular fluids. In The Eye, Davson H, editor. New York, 1969, Academic Press, Inc., pp. 97-99.

[2] Keith M. Meek and Craig Boote. The organization of collagen in the corneal stroma. Experimental Eye Research 2004;78: 503-12.

[3] Pfister RR, Paterson CA, and Hayes SA: Topical ascorbate decreases the incidence of corneal ulceration after experimental alkali burns. Invest Ophthalmol Vis Sci 17:1019, 1978.

[4] Pfister RR, Paterson CA, Spiers JW, and Hayes SA: The efficacy of ascorbate treatment after severe experimental alkali burns depends upon the route of administration. Invest Ophthalmol Vis Sci 19:1526, 1980.

[5] Levinson RA, Paterson CA, and Pfister RR: Ascorbic acid prevents corneal ulceration and perforation following experimental alkali burns. Invest Ophthalmol 15:986, 1976.

[6] Pfister RR and Paterson CA: Additional clinical and morphological observations on the favorable effect of ascorbate in experimental ocular alkali burns. Invest Ophthalmol Vis Sci 16:478, 1977.

[7] Kasetsuwan N, Wu FM, Hsieh F, Sanchez D, McDonnell PJ. Effect of topical ascorbic acid on free radical tissue damage and inflammatory cell influx in the cornea after excimer laser corneal surgery. Arch Ophthalmol. 1999 May;117 (5):649-52.

[8] Brian Reid, Bing Song, Colin D. McCaig, and Min Zhao. Wound healing in rat cornea: the role of electric currents Faseb J. 2005; 19: 379-86. 